\title{
Re-modeling Urban Poverty: A Multidimensional Approach
}

\author{
Jamalludin Sulaiman', Azlinda Azman², Zahoor Khan 3,* \\ ${ }^{1}$ Professor, School of Social Sciences, Universiti Sains Malaysia, 11800 Penang, Malaysia \\ ${ }^{2}$ Associate Professor, School of Social Sciences, Universiti Sains Malaysia, 11800 Penang, Malaysia \\ ${ }^{3} \mathrm{PhD}$ candidate, School of Social Sciences, Universiti Sains Malaysia, 11800 Penang, Malaysia \\ *Corresponding Author: zahoor_660@hotmail.com
}

\begin{abstract}
Growth and development without giving due attention to income and spatial distribution can be imposing and provide new challenges to poverty issues. The rural-urban exodus of the poor for better economic opportunities, landed in an environment even more devastating to many of the migrants. Although some having access to a decent standard of life, many ended up in pathetic living conditions. This discourse aims to investigate urban poverty in urban dimensions of poverty rather to measure it by income line approach which often does not represent an appropriate yardstick of poverty measurement. This proposal introduces a set of various urban poverty based dimensions index to be referred as the Multidimensional Urban Poverty Index (MUPI) to re-evaluate the urban poverty on a wider socioeconomic scale. The proposed index consists of economic, socioeconomic, financial accessibility, living conditions and social fragmentation dimensions. The dimensions are aggregated, by assigning different weights based on previous theoretical and empirical studies. Conceptualization and measurement of urban poverty within the urban dimensions have valuable policy implications and targets the marginalized communities in the urban areas. The study will contribute to the existing field of knowledge at one hand and will contribute to better outreach efforts by the state to help the nation's development agenda. The national poverty line index is not appropriate to identify the urban poor given its many limitations. This study integrates selected weighted socioeconomic indicators to reveal a more comprehensive picture of the deprivations and human rights violations based on accepted urban dimensions.
\end{abstract}

Keywords Urban Poverty, New Approach, Multidimensional Assessment

\section{Introduction}

The issue of poverty and the socioeconomic conditions of the general population has remained a big challenge since human civilization. Poverty is still a persistent issue in Asia and is on the rise in some countries which in turn is further worsening the access of the poor to the economic opportunities through which they could build up their assets and enhance income in order to come out of the poverty cycle (Naseem, 2003). Unlike the slow growing developing countries, the rapid growing countries like Malaysia, Singapore and Taiwan have made remarkable progress in the field of economics and have magically resolved the issue of inequality, gender disparity and financial exclusion on a wider scale. The incidence of poverty and hard core poor have alleviated at large but rapid growth, rural urban migration and urban expansion has posed new challenges of urban poverty on rapid growing economies (Baker \& Schuler, 2004).

The rural-urban exodus of the poor for better economic opportunities, landed in an environment even more devastating to many of the migrants. Although some having access to a decent standard of life, many ended up in pathetic living conditions. Living in the urban areas imposes extra expenses upon the poor in different ways. A same basket of basic goods and services are relatively more expensive in urban areas. The rural poor enjoy some basic facilities such as access to drinking water, fuel for cooking, housing, social security (from family members and relatives). The urban poor spent a substantial amount of their scarce earnings to have access to these facilities. Moreover, the urban poor are more vulnerable to natural disasters and human diseases due to living in unsafe places, high pollution and environmental hazards.

The dimensions of poverty in the urban areas are different than the dimensions in the rural areas. Some important dimensions of urban poverty are given by Baker and Schuler (2004) as;

- Commoditization (reliance on the cash economy)

- Overcrowded living conditions (slums and unsafe houses)

- Environmental hazard (stemming from the density and hazardous location of settlements, and exposure to multiple pollutants 
- Social fragmentation (lack of community and inter-household mechanisms for social security, relative to those in rural areas)

- Crime and violence

In order to identify urban poor, there is a need to assess the changing determinants of urban poverty in urban dimensions rather to use a single measure of poverty for both urban and rural poor.

\section{Conceptualization of Poverty}

Poverty is often considered as lacking or deficiency of economic resources. For many years this situation is explained through the perspective of material shortcomings, especially from the income perspective. However, poverty is no longer objectively defined, but exists in a multidimensional nature (Narayan, 2000). The selection of poverty assessment method identifies the targeted group of the poor. The application of correct measurement is essential in identifying certain target groups which will enable the researchers to suggest appropriate policies in addressing the issue of poverty. Each definition would describe the poor differently and would result in different estimation and extent of poverty (Rasool, Harun, Salleh, \& Idris, 2011). In order to comprehend urban poverty, we have to go through the established definitions and concepts of poverty.

\section{Monetary Approach}

The most commonly used approach by the economists to explain poverty is the monetary approach. Mitlin (2004) analyzed 23 poverty reduction strategies papers. He found that income/expenditure approach is the most commonly used techniques to identify the poor. This approach concentrates poverty as monetary phenomenon. Under the monetary approach, poverty may either be defined in terms of international monetary line approach or national poverty line approach. The names of the countries that prefer this approach are given table- 1 .

\section{Basic Needs Approach}

The basic needs approach has long history and it became widely discussed and practiced in late 1970s. The philosophy behind the basic needs approach is that everyone should be able to pursue well-being. The central notion of the basic needs approach is essentially materialistic. It works by identifying a bundle of basic consumption and assess whether the population has adequate access to it or otherwise. It has been generally accepted that the package should contain commodities that are universally needed, such as shelter, sanitation, clean water, food etc., however, there has been no universal agreement on what the bundle should precisely contain. Proponents argue that such package would essentially guarantee a person's subsistence. If any individual has inadequate access to these commodities, then he/she may be considered as poor, and vice versa.

\section{Capability Approach}

Capability approach was originally developed by Sen (1985). This approach includes non-income components such as life expectancy, literacy and infant mortality to measure poverty. Sen (1985) concentrated on the quality of life and emphasized on the removing of obstacles so that people could have more freedom to function. He explained basic capability as the freedom to do basic activities necessary to avoid poverty. The capability approach explains how individuals function to achieve their different needs. Robeyns (2005) emphasized that capability approach put emphasis on on what people are effectively able to do.

\section{Social Exclusion Approach}

Social exclusion is defined as 'a process when individuals or groups are excluded whether fully or partially from the participation with the society they live in' (Townsend, 1987). Townshed (1987) explained that a community or group of people will be considered as deprived who are excluded by ordinary living pattern, customs and activities. Taylor (1999) further supported the idea of social exclusion approach in explaining poverty using the economic, political and cultural dimensions.

\section{Poverty Participation Approach (PPA)}

This method provides an inside view about poverty that how the poor by themselves perceive poverty? The earlier methods explained poverty from the perspective of policy makers and researchers but this approach provides an insight into poverty from the victims of the poverty perspectives. Chambers (1997) originated this approach. He pointed out that the participation of the poor themselves in decisions and policies is vital in understanding the meaning and extent of poverty. This approach surprisingly revealed that the poor focused on physical, human, social and environmental issues instead of income as the phenomena of poverty.

\section{Multidimensional Poverty Approach}

Income poverty provides useful information but poor people themselves define poverty more broadly to include lack of education, health, housing, empowerment, employment, personal security and more. No one indicator, such as income, is exclusively able to capture the multiple aspects that contribute to poverty. The Multidimensional Poverty Index (MPI) is an index designed to measure acute poverty (Alkire \& Santos, 2011). Acute poverty refers to two main characteristics. First, it includes people living under conditions where they do not reach the minimum 
internationally agreed standards in indicators of basic functioning's, such as being well nourished, being educated or drinking clean water. Second, it refers to people living under conditions where they do not reach the minimum standards in several aspects at the same time (Alkire \& Santos, 2011). Table-1: Poverty identification; evidence from poverty reduction startegies papers is given in Appendix-1. In a nutshell, there is no consensus among the researchers and policy holders regarding the definition of poverty. Although money metric approach is commonly used to measure poverty in terms of income or expenditure however, this approach has its own shortcomings. Recently, Malaysia revised its definition of poverty and thus differentiated poverty income line for rural and urban, and statistics according to the respective needs and macroeconomic situation of the areas (Rasool et al., 2011). The major drawback of this approach is that it concentrates on monetary aspect while undermine the non-monetary aspects (Chambers, 1997). Understanding urban poverty presents a set of issues distinct from general poverty analysis and thus may require additional tools and techniques. This paper proposes to index urban poverty in terms of 'multidimensional urban deprivations'. The existing measurements of urban poverty have been given in appendix-1. Taking into consideration the existing literature about rural and urban poverty and major poverty assessment methods the following can be concluded:

1. Poverty cannot be measured using uni-dimensional (income or expenditure) context.

2. There is a difference between urban and rural poverty and their corresponding determinants.

3. The process of rapid growth and economic expansion impose greater challenges of urban poverty.

Relative to rural poverty, urban poverty received less attention and thus resulting in the urban poor being marginalized and invisible in the radar screens of government poverty alleviation programs

\section{Why A New Urban Poverty Assessment Methodology?}

The major poverty assessment methods suffer from some measurement biases like the money metric approach suffers from non-monetary aspects measurements. Another drawback of the income approach to capture poverty is that even if it is possible to specify the minimum thresholds of each and all basic needs and put a price tag on them and aggregate across minimum thresholds to derive the monetary poverty line, there is no guarantee that individuals with incomes at or even above the poverty line would actually allocate their incomes so as to purchase the minimum basic needs bundle. The capability approach presumes that individuals are well enough endowed so that they have the freedom to choose an appropriate non-poor functioning. The inherent difficulty with this approach to poverty is that it is in practice very difficult (Thorbecke, 2005). The basic needs approach suffers from standardized minimum thresholds. The minimum standards are not alike in rural and urban areas and across the nations and spaces (Thorbecke, 2005). The recently developed multidimensional poverty index is a comprehensive poverty index (MPI) to investigate multiple deprivations but unfortunately this is also not free from some serious problems. The indicators of MPI include both outputs, such as years of schooling, and inputs, such as cooking fuel. It also includes both stock and flow indicators. A stock indicator is measured at a particular point in time, and it may have accumulated in the past.

\section{Technical Box-1: Components of MUDI}

The MUDI is composed of five dimensions made up of
ten indicators. Associated with each indicator is a
minimum level of satisfaction, which is based on
intemational consensus (such as the Millennium
Development Goals or MDGs). This minimum level of
satisfaction is called a deprivation cut-off. Two steps
are then followed to calculate the MDI:
Step 1: Each person is assessed based on household
achievements to determine if he/she is below the
deprivation cut-off in each indicator. People below the
cut-offare considered deprived in that indicator.
Step 2: The deprivation of each person is weighted by
the indicator's weight If the sum of the weighted
deprivations is 25 percent or more of possible
deprivations, the person is considered to be
multidimensional deprived.
Source: Alkire and Santos (2010)

\section{Steps towards the Development of MUDI}

\author{
Multidimensional Deprivation Index Construction \\ Requires Several Steps. We Explain These Steps One By \\ One
}

\section{Economics Dimension}

Economic dimension represents the economic aspects of the households. Economic dimension comprises of three aspects; income, saving, and ownership of residential house. Information about income, saving and ownership of residential house represent finical health of the household, their vulnerability to economic deprivation and their suitability for credit. A household will be considered deprived on economic dimension if none of the household member has a regular source of income equal or above the international poverty line (US\$2 per day) for at least 6 months. Similarly, if a household cannot save a minimum amount (equal to one school going child tuition fee) on a regular bases for at least 6 months then the household will be considered as deprived on economic dimension. If a household member does not live in a safe house then the members of the household are deprived on economic dimension. 


\section{Environmental Hazards}

Environmental hazard is another dimension of MUDI. This dimension is represented by the status of the home (condition of the house) in which the members of the households are living. If the household members are living in slums they are vulnerable to multidimensional poor and vice versa.

\section{Financial Accessibility}

Financial accessibility is another dimension of MUDI. This dimension represents the access of households to formal financial institutions for fulfilling their basic needs such as credit, saving and insurance. An inability on these aspects represents a deprivation on financial aspects. If a household member does not have an access to conventional financial institutions for credit or insurance then the household is deprived on financial accessibility dimension.

\section{Living Conditions}

Living conditions such as access to clean drinking water, electricity and adequate sanitation represent a direct measure of standard of life. An assessment on these aspects represents a direct picture that whether the intervention of MFIs has brought any changes to living standard of the clients or vice versa. The household is considered as deprived if the household does have access to clean drinking water or clean water is more than 30 minutes' walk from home (roundtrip time). Similarly, the household is deprived, on living conditions dimensions, if the household members share toilet. Finally, the household is deprived on living conditions, if the household has no electricity.

\section{Women Empowerment}

Women empowerment is the last dimension of MPI.
Women empowerment is represented by two indicators; share of women in household income and women participations in Government election. This is a critical aspect which represents the participation of women in Eco-political activities. This aspect particularly represents the role of IMFIs towards the achievement of their social goals. Any positive change in these aspects resulting from the intervention of IMFIs will represent the achievement of their social goals and vice versa. Eventually, microfinance performance index has been developed to represent aggregate socioeconomic impact as a single index.

\section{Social Fragmentation}

Social fragmentation is one of the leading problems of the urban poverty. Social fragmentation has been represented by financial and social support of the community for affected household. If a household members do not receive financial and social support at the time of any misshape or emergency the household is considered deprived and socially fragmented. The indicators cut offs has been given in Appex-1, Table-3.

\section{Indicators' Weights}

The indicators of MUDI are assigned double equal weight. All dimensions are weighted equally and then all indicators within each dimension are weighted equally. The details about weight and indicators are given in the following table-1.

Table-1 shows detail about dimensions, indicators and weight assigned to each dimension and indicator. The weight is assigned to each dimension and indicator by double equal weight process - first equal weight is assigned to each dimension and then equal weight is assigned to each indicator within each dimension. The dimensions and indicators represent the socioeconomic and institutional deprivations.

Table1. Composition of MUDI, Dimensions, weights and Indicators

\begin{tabular}{|c|c|c|c|c|}
\hline \multirow{7}{*}{} & Dimensions & $\begin{array}{c}\text { Dimensional } \\
\text { weight }\end{array}$ & Indicators & $\begin{array}{c}\text { Indicators } \\
\text { weight }\end{array}$ \\
\cline { 2 - 5 } & Economic & $20 \%(1 / 5)$ & $\begin{array}{c}\text { No regular source of income } \\
\text { No regular saving }\end{array}$ & $10 \%$ \\
\cline { 2 - 5 } & $\begin{array}{c}\text { Environmental } \\
\text { hazards }\end{array}$ & $20 \%(1 / 5)$ & $\begin{array}{c}\text { Deprived if the household members live in slums or } \\
\text { unsafe house }\end{array}$ & $20 \%$ \\
\cline { 2 - 5 } & $\begin{array}{c}\text { Financial } \\
\text { accessibility }\end{array}$ & $20 \%(1 / 5)$ & $\begin{array}{c}\text { No access to formal Financial institution for credit } \\
\text { No access to formal Financial institution for insurance }\end{array}$ & $10 \%$ \\
\cline { 2 - 5 } & Living conditions & $20 \%(1 / 5)$ & $\begin{array}{c}\text { No access to clean drinking water } \\
\text { No access to adequate sanitation } \\
\text { No electricity }\end{array}$ & $6.66 \%$ \\
\cline { 2 - 5 } & $\begin{array}{c}\text { Social } \\
\text { Fragmentation }\end{array}$ & $20 \%(1 / 5)$ & $\begin{array}{c}\text { Deprived if the household members do not get any } \\
\text { financial support from their community. } \\
\text { Deprived if the household members are not being visited } \\
1 / 3^{\text {rd }} \text { of the community members after any emergency } \\
\text { situation. }\end{array}$ & $10 \%$ \\
\hline
\end{tabular}

Source: Developed by the authors 


\section{The Aggregate Deprivation Cut-Off}

The deprivation score of each household is calculated with the help of a weighted sum of the number of deprivations, so that the deprivation score for each person lies between 0 and 100. The score increases as the number of deprivations of the person increases and reaches its maximum of 100 when the client is deprived in all component indicators. A person, who is not deprived in any indicator, receives a score equal to 0 . Thus;

$0 \rightarrow$ no deprivation at all on the selected indicators.

$100 \rightarrow$ multidimensional deprivations based on the selected indicators.

Intensity of multidimensional deprivation is negligible if household score is less than 20. Moderate multidimensional deprived if household score is b/w 20 and 50. High multidimensional deprived if household score is $>50$ but less than 75. Very high multidimensional deprived if the household score is $>75$.

\section{Technical Box-2: The Definition of MUDI}

The MUDI is an index designed to measure households'
deprivations in diverse dimensions. The poor are not
deprived in a single aspect (income or health or social
aspects etc.) rather they are deprived in multiple aspects
therefore; a proper investigation will reveal their
multidimensional deprivations based on selected
indicators at one hand while the intensity of deprivations
for each dimension on the other hand. The MUDI helps to
identify incidence of urban deprivation and intensity of
urban deprivation. The combination of both; the
incidence of urban poverty and intensity of urban
deprivation provides insight into pattern of urban
deprivation such as what is the contribution of each
indicator and dimension in total deprivation?
Source: Alkire and Santos (2010)

\section{Multidimensional Urban Deprivation Index}

The MUDI is an index designed to measure households' deprivations in diverse dimensions. The poor are not deprived in a single aspect (income or health or social aspects etc.) rather they are deprived in multiple aspects therefore; a proper investigation will reveal their multidimensional deprivations based on selected indicators at one hand while the intensity of deprivations for each dimension on the other hand.

The combination of both: incidence of urban deprivation and intensity of urban deprivations will finally yield Multidimensional Urban Deprivation Index (MUDI). MUDI $=$ (Intensity of urban deprivation)*(Incidence urban of deprivation). The following Table-1 shows artificial data to construct MUDI.

\section{Interpretation of Results}

Keeping into consideration the result of table-2, 73.08 percent of the people are multidimensional poor. It has also shown that on average the poor households are deprived by 66.04 percent on the weighted indicators. The MUPI represents the share of the population that is multidimensional poor adjusted by the intensity of the deprivation suffered. Thus the MUDI value is:

MUDI $=($ Intensity of deprivation $) *($ Incidence of deprivation) $=0.6604 * 73.08=48.26$

So 48.26 percent households are multidimensional deprived. Furthermore, MUDI is capable to report deprivation; dimension by dimension and indicator by indicator. The above example shows that the community is particularly suffering from financial accessibility deprivation and social deprivation based on the selected indicators. Similarly, the dimensions based deprivations show that improvement financial and social support is more important than the other indicators but the community is particularly suffering from these deprivations more than the rest of dimensions of deprivation.

\section{Poverty and Human Rights}

There is no doubt that freedom from severe poverty is among the most important basic human rights. We are physical being who need access to safe food and water, clothing, shelter, and basic medical care in order to live well or to live at all. People living in severe property lack secure access to sufficient quantities of these basic necessities. Two out of five children in the developing world are stunted, one in three is underweight, and one in ten is wasted. Some 250 Million children between five and 14 do wage work outside their household and often under harsh or cruel conditions.

There is a strong relationship between poverty and human rights. The relationship is direct in the case of basic social and economic human rights, such as the right to a standard of living adequate for the health and well-being of oneself and one's family, including food, clothing, and housing. The connection is more indirect in the case of civil and political human rights associated with democratic government and the rule of law.

The investigation of deprivations on socioeconomic conditions definitely represents identification of socioeconomic violation of human rights. Thus, this study also shed light on the violation of human rights in terms of selected dimensions in urban areas. For example Table-2 shows that the urban poor are particularly suffering from social rights violation in the form of social fragmentation and economic rights violation in the form living conditions dimensions. 
Table 2. An artificial example to develop a Multidimensional Urban Deprivation Index (MUMUDIDI)

\begin{tabular}{|c|c|c|c|c|c|c|c|c|}
\hline Indicators & 1 & 2 & 3 & 4 & 5 & weights & $\operatorname{IBD}(\%)$ & $\mathrm{DD}(\%)$ \\
\hline Household size & 5 & 7 & 6 & 4 & 4 & & & \\
\hline \multicolumn{9}{|l|}{ Economic } \\
\hline No regular source of income & 1 & 0 & 1 & 1 & 0 & 0.10 & 60 & \\
\hline No regular saving & 1 & 1 & 0 & 0 & 1 & 0.10 & 60 & 53 \\
\hline \multicolumn{9}{|l|}{ Environmental hazards } \\
\hline No safe residential house & 0 & 0 & 1 & 1 & 0 & 0.20 & 40 & 40 \\
\hline \multicolumn{9}{|l|}{ Financial accessibility } \\
\hline No access to formal Financial institution for credit & 1 & 0 & 1 & 1 & 1 & 0.10 & 80 & \multirow{2}{*}{50} \\
\hline No access to formal Financial institution for insurance & 0 & 0 & 1 & 0 & 0 & 0.10 & 20 & \\
\hline \multicolumn{9}{|l|}{ Living conditions } \\
\hline No access to clean drinking water & 1 & 0 & 0 & 1 & 1 & 0.066 & 60 & \multirow{3}{*}{60} \\
\hline No access to adequate sanitation & 1 & 1 & 1 & 0 & 1 & 0.066 & 80 & \\
\hline No electricity & 1 & 0 & 0 & 0 & 1 & 0.066 & 40 & \\
\hline \multicolumn{9}{|l|}{ Social fragmentation } \\
\hline No financial support in case of emergency & 1 & 0 & 1 & 0 & 1 & 0.10 & 60 & \multirow{2}{*}{60} \\
\hline No social support in case of emergency & 1 & 0 & 0 & 1 & 1 & 0.10 & 60 & \\
\hline $\begin{array}{l}\text { Socioeconomic outcome (Household deprivation on socioeconomic conditions) } \\
\text { Households Socioeconomics deprivation status }\end{array}$ & & $\begin{array}{l}79.16 \\
\text { deprived }\end{array}$ & $\begin{array}{c}16.66 \\
\text { not } \\
\text { deprived }\end{array}$ & $\begin{array}{c}62.5 \\
\text { deprived }\end{array}$ & $\begin{array}{l}50 \\
\text { deprived }\end{array}$ & $\begin{array}{c}71 \\
\text { deprived }\end{array}$ & & \\
\hline Intensity of deprivation & & high & negligible & high & moderate & high & & \\
\hline Multidimensional deprived households & & 0.730769 & 73.08 & & & & & \\
\hline Intensity of deprivation & & 66.04211 & & & & & & \\
\hline Multidimensional deprivation for an intervention area & & 0.660421 & 48.26 & & & & & \\
\hline
\end{tabular}




\section{Conclusion and Policy Implications}

This paper briefly evaluates the existing poverty assessment approaches. None of the approach can be used as a single poverty assessment method due to its many flaws. The policy implications of the study are three folds; firstly, it will open up a new dimension of literature in the field of urban poverty by instigating an important area among the academicians and researchers. Secondly, it will provide a better alternative to the stakeholders to investigate urban poverty in terms of urban dimensions on a wider socioeconomic scale rather than a few economic indicators. Last but not the least; the study integrates diverse socioeconomic indicators, after assigning weights and adjustment for inequalities, to depict an overall picture of deprivations and human rights violations using the selected urban dimension.

\section{Appendix-1}

Table 1. Major Poverty Assessment Methods Along with Advantages and Disadvantages

\begin{tabular}{|c|c|c|c|c|}
\hline $\begin{array}{l}\text { Poverty Measurement } \\
\text { Approach }\end{array}$ & Dimensions & Indicators & Advantages & Disadvantages \\
\hline $\begin{array}{l}\text { Poverty Line Income } \\
\text { (PLI) approach }\end{array}$ & $\begin{array}{l}\text { Income or } \\
\text { expenditure }\end{array}$ & $\begin{array}{l}\text { A particular level of } \\
\text { income necessary to } \\
\text { purchase a basket of basic } \\
\text { items to sustain life. }\end{array}$ & $\begin{array}{c}\text { Easy to calculate } \\
\text { Quantitative in nature } \\
\text { Can be used for the detection } \\
\text { rural and urban poverty } \\
\text { Can be adjusted for } \\
\text { heterogeneity }\end{array}$ & $\begin{array}{l}\text { One-dimensional } \\
\text { Ignore important aspects of poverty }\end{array}$ \\
\hline $\begin{array}{l}\text { Multidimensional } \\
\text { Poverty Index (MPI) }\end{array}$ & $\begin{array}{l}\text { Education } \\
\text { Health } \\
\text { Standard of } \\
\text { living }\end{array}$ & $\begin{array}{l}\text { Years of schooling } \\
\text { Child enrollment } \\
\text { Child mortality } \\
\text { Nutrition } \\
\text { Electricity } \\
\text { Drinking water } \\
\text { Sanitation } \\
\text { Flooring } \\
\text { Cooking fuel } \\
\text { assets }\end{array}$ & $\begin{array}{c}\text { Comprehensive } \\
\text { Quantitative in nature } \\
\text { Applicable across the different } \\
\text { regions } \\
\text { Provides more reliable } \\
\text { information about poverty }\end{array}$ & $\begin{array}{l}\text { General in nature } \\
\text { Does not differentiate between rural } \\
\text { and urban poverty } \\
\text { Does not provide an insight into urban } \\
\text { income in detail } \\
\text { Does not take into account urban } \\
\text { poverty features like commoditization } \\
\text { the poor economy, social security, } \\
\text { access to finance etc. } \\
\text { Having technical flows like combine } \\
\text { stock and variable concepts. }\end{array}$ \\
\hline $\begin{array}{l}\text { Human Poverty Index } \\
\text { (HPI) }\end{array}$ & $\begin{array}{l}\text { Life } \\
\text { expectancy } \\
\text { knowledge } \\
\text { Economic } \\
\text { deprivation }\end{array}$ & $\begin{array}{l}\text { The percentage of } \\
\text { persons who cannot live } \\
\text { more than } 40 \text { years of age } \\
\text { Adult literacy } \\
\text { The percentage of people } \\
\text { who do not have access to } \\
\text { basic facilities }\end{array}$ & $\begin{array}{c}\text { Multidimensional approach } \\
\text { Quantitative in nature } \\
\text { Easily applicable } \\
\text { Can be used across the different } \\
\text { regions }\end{array}$ & $\begin{array}{c}\text { General in nature } \\
\text { Does not differentiate between rural } \\
\text { and urban poverty } \\
\text { Does not provide an insight into urban } \\
\text { income and expenditure in detail } \\
\text { Does not take into account urban } \\
\text { poverty features like commoditization } \\
\text { of the poor economy, social security, } \\
\text { access to finance etc. }\end{array}$ \\
\hline $\begin{array}{l}\text { Participatory Poverty } \\
\text { Assessment (PPA) }\end{array}$ & $\begin{array}{l}\text { Understating } \\
\text { poverty in } \\
\text { local, social } \\
\text { and } \\
\text { institutional } \\
\text { context }\end{array}$ & $\begin{array}{c}\text { Social indicators of } \\
\text { poverty } \\
\text { Local concept of poverty } \\
\text { Political indicators of } \\
\text { poverty } \\
\text { Institutional indicators of } \\
\text { poverty }\end{array}$ & $\begin{array}{l}\text { A comprehensive approach } \\
\text { Covers the social, political and } \\
\text { institutional aspects of poverty } \\
\text { Participatory approach } \\
\text { Capable to incorporate urban } \\
\text { dimensions of poverty }\end{array}$ & $\begin{array}{l}\text { Qualitative in nature approach which } \\
\text { cannot be generalized. } \\
\text { Less rigorous scientifically } \\
\text { Difficult in analysis }\end{array}$ \\
\hline
\end{tabular}


Table2. Major poverty Assessment Measure

\begin{tabular}{|c|c|c|c|}
\hline & Income/expenditure & Basic needs & other \\
\hline $\begin{array}{c}\text { Major means of } \\
\text { identification }\end{array}$ & $\begin{array}{c}\text { Benin, Burkina Faso, Ethiopia, Gambia, } \\
\text { Ghana, } \\
\text { Malawi,Mauritania,Mozambique,Niger,R } \\
\text { wanda,Senegal.Tanzania,Uganda,Zambia, } \\
\text { Bolivia,Guyana,Honduras,Nicaragua,Cam } \\
\text { bodia,Sri Lanka, Vietnam, Yemen }\end{array}$ & $\begin{array}{c}\text { Mali, Tanzania, Bolivia, } \\
\text { Guyana, Honduras }\end{array}$ & $\begin{array}{c}\text { Burkina Faso(PPA), Ghana(health), } \\
\text { Mali(potential poverty-lack of assets), } \\
\text { Mozambique(PPA),Niger (PPA),Rwanda } \\
\begin{array}{c}\text { Minor means of } \\
\text { identification }\end{array}\end{array}$ \\
\hline Mali & $\begin{array}{c}\text { Benin, Mauritania, } \\
\text { Mozambique, Rwanda, } \\
\text { Zambia, Nicaragua } \\
\text { indicators such as children's stunting), } \\
\text { Bolivia(malnutrition indicators, national } \\
\text { dialogue) }\end{array}$ \\
\hline
\end{tabular}

Technical Box-3. Thresholds of MUDI

\begin{tabular}{|c|c|}
\hline \multicolumn{2}{|l|}{ 1. Economic indicators } \\
\hline No regular income & $\begin{array}{l}\text { Deprived if none of the household member has regular income equal or } \\
\text { above the international poverty line (US\$ } 2 \text { per day) for at least } 6 \text { months }\end{array}$ \\
\hline No regular saving & Deprived if none of the household member saves on regular basis. \\
\hline \multicolumn{2}{|l|}{ 2. Environmental hazards } \\
\hline No safe residential house & Deprived if the household members live in slums or unsafe house \\
\hline \multicolumn{2}{|l|}{ 3. Financial accessibility } \\
\hline No access to formal financial institution for credit & $\begin{array}{l}\text { Deprived if household members don't have access to financial } \\
\text { institutions for credit }\end{array}$ \\
\hline No access to formal financial institution for insurance & $\begin{array}{c}\text { Deprived if household members don't have access to financial } \\
\text { institutions for insurance }\end{array}$ \\
\hline \multicolumn{2}{|l|}{ 4. Living conditions } \\
\hline No access to clean drinking water: & $\begin{array}{l}\text { Deprived if a household does have access to clean drinking water or } \\
\text { clean water is more than } 30 \text { minutes' walk from home (roundtrip time). }\end{array}$ \\
\hline No access to adequate sanitation & Deprived if the household members share toilet \\
\hline No electricity: & Deprived if the household has no electricity \\
\hline \multicolumn{2}{|l|}{ 5. Social fragmentation } \\
\hline No financial support in case of emergency & $\begin{array}{l}\text { Deprived if the household members do not get any financial support } \\
\text { from their community. }\end{array}$ \\
\hline No social support in case of emergency & $\begin{array}{l}\text { Deprived if the household members are not being visited } 1 / 3^{\text {rd }} \text { of the } \\
\text { community members after any emergency situation. }\end{array}$ \\
\hline
\end{tabular}

\section{REFERENCES}

Alkire, S., \& Santos, M. E. (2010). Training Material for Producing National Human Development Reports.

Alkire, S., \& Santos, M. E. (2011). Acute multidimensional poverty: a new index for developing countries.

Baker, J. L., \& Schuler, N. (2004). Analyzing urban poverty: a summary of methods and approaches (Vol. 3399): World Bank Publications.

Chambers, R. (1997). Whose reality counts?: putting the first last: Intermediate Technology Publications Ltd (ITP).
Mitlin, D. (2004). Understanding urban poverty; what the Poverty Reduction Strategy Papers tell us (Vol. 13): Iied.

Narayan, D. (2000). with R. Patel, K. Schafft, A. Rademacher and S. Koch-Schulte (2000) Voices of the Poor: Can Anyone Hear Us: Oxford University Press for the World Bank.

Naseem, S. M. (2003). Rural development and poverty in south Asia: New York: United Nations.

Rasool, M. S. A., Harun, M. F. M., Salleh, A. M., \& Idris, N. (2011). Poverty measurement in Malaysia: a survey of the literature. Akademika, 81(1), 73-81.

Robeyns, I. (2005). The capability approach: a theoretical survey. Journal of human development, 6(1), 93-117.

Sen, A. (1985). Commodities and Capabilities North-Holland: Amsterdam. 
Taylor, P. (1999). Democratizing cities: habitat's global campaign on urban governance'. Habitat Debate, 5(4), 1-5.

Thorbecke, E. (2005). Multidimensional poverty: Conceptual and measurement issues. Paper presented at the international conference on "The Many Dimensions of Poverty," Brasilia, August.

Townsend, P. (1987). Deprivation. Journal of social policy, 16(02), 125-146. 